\title{
国内外の農政における環境保全の位置づけ
}

\section{Agrienvironmental Policies in North America, Europe and Japan}

\author{
横張 真* \\ Makoto YOKOHARI
}

農業がもつ環境保全上の役割はなにか。これは，最近の 農政をめぐる話題のなかでも，とくに注目すべきもののひ とつといえる。本稿では, OECD「農業と環境」部会の専門 家会合や，新農業基本法制定にあたっての基礎データ作成 などにたずさわった経験にもとづき，国内外での農政にお ける農業の環境保全機能の位置づけを概観し，今後の環境 保全をめぐる農政の展開に際して考慮すべき点を展望する。

\section{WTO 閣僚会議における「農業の多面的機能」}

1999 年 12 月にアメリカ・シアトルで開催された WTO （世界貿易機関）閣僚会議では，「農業の多面的機能」が議 論の焦点のひとつとなった。GATTウルグアイラウンド 合意以降, 農産物の工業製品並みの貿易自由化が国際的な 趨勢にあるなかで，日本はこれまで一貫して，米作を中心 に農業保護的な政策を堅持してきた。しかし，アメリカや オーストラリアなどの農産物輸出国による市場開放に対す る圧力の高まりのなかで，日本の政策は窮地に追い込まれ つつある。

「農業の多面的機能」は, 日本が従来の政策を保持する ための窮余の主張であった。『農業は農産物の生産以外に, 景観の保全や水かん養, 生物相保全など環境保全上の様々 な機能を有している。農業政策は環境政策としての面むあ るのだから，生産機能だけを取り上げて，農業保護の撤廃 を論ずるべきではない』というわけである。日本と同様に， 農業に環境保全上の役割を認める EU 諸国もこの主張に同 調するはずとの目論見のもと, 同主張は, 農業保護の切り 札となるべくWTOの場に持ち込まれた。しかし，政治的 な駆け引きのなかで結局，主張は明文化されず，議論が持 ち越されたことは周知のとおりである。

\section{OECD「農業と環境」}

農業と環境保全の問題は，WTOのみならず，OECD （経済協力開発機構）の場でも継続的な議論がなされてき た。OECDでは, 1992 年のブラジル・リオデジャネイロ
における環境サミットや, 1993 年の GATT ウルグアイラ ウンド合意などを受けて，農産物の自由貿易体制のもとて の, 農業と環境保全にかかわる国際的なルールづくりの必 要性が指摘されてきた。「農業と環境」部会は，こうした 動きを受けて，1993 年に農業委員会と環境政策委員会の 合同部会として発足した。その役割は，農業が環境にもた らすプラス/マイナス影響を表す世界共通の指標（農業環 境指標）を策定し， OECD 加盟各国による農業政策の環 境保全面での妥当性を評価することにある（OECD，1997）。 環境保全を唱った農業保護的な政策が本当に妥当なのか, 単なる言い訳なのかを共通の指標により判定し，言い訳に すぎないとされた場合には，政策の見直しを勧告しようと いうわけである。策定対象之なった指標は，表 1 に示す 13 種である。度重なる専門家会合を通じて指標策定が進 められてきた。なかでも 1998 年 10 月にイギリス・ヨーク で開催された会合では, 全指標について策定の現状と将来 方向が確認されている（OECD, 1999a, OECD, 1999b)。

指標策定をめぐる各国の主張には, その国の農業の現状 が色濃く反映されており，興味深い。アメリカ，オースト ラリアなどの農産物輸出国は，農業は環境に対しマイナス

\section{表－ 1 OECD「農業と環境」部会の策定する 農業環境指標（OECD，1997）}
1. Agriculture nutrient use
2. Agriculture pesticide
3. Agriculture water use
4. Agriculture land use and conservation
5. Agriculture soil quality
6. Agriculture and water quality
7. Agriculture greenhouse gases
8. Agriculture and biodiversity
9. Agriculture and wildlife
10. Agriculture landscape
11. Farm management
12. Farm financial resources
13. Socio-cultural issues in relation to agriculture

*筑波大学社会工学系 
影響をむたらすむのとの認識を出発点とし,「Nutrient use」 「Pesticide use」といったマイナス指標の重要性を強調す る。『農業は環境を破壊する罪深い行為である。しかし， 各国がその風土に見合った低投入持続型農業（LISA）の 普及をすすめ, 自由貿易体制のもと，お互いの農産物を取 り引きすれば，世界的に見て環境負荷が軽減される。だか ら一切の農業保護政策は否定すべき』というのが, 彼らの 主張である。

これに真っ向から対立するのが，EU諸国の主張である。 『農業は景観や生物相保全など，環境に対して多くのプラ ス影響をむつ。そこで「Biodiversity」「Wildlife habitat」 「Landscape」などのプラス指標により農業を評価し，環 境保全上，一定の役割が認められた場合には，農業保護政 策が必要』というわけである。彼らの主張の背景には，山 岳農民対策などの条件不利地に対する農業支援策が，環境 保全を名目に，すでに講じられているという事情がある。

日本は言うまでもなく，EU諸国と基本的には同じ立場 に立ってきた。ただし，EU諸国が景観や生物相の保全を 中心とするのに対して, 日本の主張は, 水かん養や土砂崩 壊防止，士壌浸食防止など，国土保全上の機能に重きを置 いている点が異なる。実際,「Land use and conservation」 指標の作成は日本が主導しており，農林水産省の研究機関 で開発が進められてきた評価手法が基礎となっている (Kato et al, 1997)。

\section{食料・農業・農村基本法}

一方，国内の農政についても，環境保全をめぐって大き な転換が図られつつある。日本の農政はこれまで, 昭和 36 年に制定された農業基本法を法的根拠としてきた。同 法の制定当時, 日本は高度経済成長の黎明期にあり, 都市 への人口集中と農村部の過疎化，農工業間の所得格差が顕 在化し始めていた。こうした時代背景のもと,「生産政策」 「構造政策」「価格・流通政策」を 3 本柱に, 工業並みの労 働生産性と, 都市並みの生活水準の達成が目指されたのが

\section{表一2 食料・農業・農村基本法に掲げられた政策目標}

(4)〜6が新たに加えられた目標。いずれも環境 保全にかかわる内容をむつ

(1) 食料安全保障（生産政策）

(2) 農業構造改革（構造政策）

（3）市場原理の導入（価格・流通政策）

(4) 中山間地域の振興（農村の国土保全機能の発 揮)

(5) 農村地域の活力増進（農村の公益的・多面的 機能の発揮)

（6) 環境と調和した持続的な生産（農業の公益的 機能の発揮)
旧農業基本法であった。

1999 年 7 月に制定された新農業基本法としての食料・ 農業・農村基本法は, 政策目標として, 従来からの 3 本柱 を継承しつつ，新たに「中山間地域の振興」「農村地域の 活力増進」「環境と調和した持続的な生産」といった，環 境保全に関連した日標が加えられている（表 2 ）。基本理 念を見ても，旧法が食料生産を絶対的なアイデンティティ としてきたのに対し, 新法は, 食料生産と並ぶ機能として 農業・農村の公益的機能を位置づけている（農林水産省ホー ムページ : http://www.maff.go.jp/)。新農業基本法は, 環境保全を農業・農村政策の柱のひとつに据えた点におい て, 日本農政の大きな転換を象徴するあのといえる。基本 法の改正を受けて, 今後, 個別法の改正屯進むものと考え られる。「環境保全」がそうした動きのなかでいかに扱わ れていくのか, 注意深く見守る必要があろう。

\section{環境保全と粗放化農業}

では，環境保全をめぐる具体的な施策には，どのような あのがあるか。最も代表的なのが，EU諸国における粗放 化農業政策であろう。環境保全を名目に，管理の頻度や質 を落とした粗放的 extensiveな農業を奨励し，その結果之 しての農産物収量の減分については, 補助金により補填す るという政策である（和泉, 1989）。農業といえども生産 にはあまり期待しない。むしろ，農家に環境や国土の管理 者としての役割を期待し，その役割に対して資金援助を行 うというわけだ。現在，イギリスやドイッ，フランスをは じめとした EU 諸国で，山岳地域などの条件不利地に対す る地域振興策のひとつとして実施されている。農業の環境 保全機能のうちでも，とくに景観保全と生物相保全（生物 多様性や八ビタートの保全）が，具体的な名目とされるこ とが多い。

なぜ「粗放化」という概念が成立するのか。ヨーロッパ 諸国の多くは, 北緯 $50^{\circ}$ 前後の高緯度地带にあり, 水河 に覆われた履歴をもつ国も多い。日本などのより低緯度の 地域と比較して, 生物多様性がもともと高くない。そうし た自然条件に加え, 森林が切り開かれ, 農地(畑地や牧野・ 草地）が国土の大半を占めるようになった結果（表 3 ）, 農業を前提とした生態系が構築されてきた。例えば，イギ

\section{表ー3 ヨーロッパと日本の農林地の面積割合}

草地・牧草地, 森林の占める割合の違いが注目される

\begin{tabular}{|c|c|c|c|}
\hline & 農耕地 & 牧野・草地 & 森林 \\
\hline ドイツ & 34 & 21 & 30 \\
\hline フランス & 35 & 28 & 27 \\
\hline イギリス & 25 & 48 & 10 \\
\hline 日 本 & 12 & 4 & 66 \\
\hline
\end{tabular}

$(\%)$ 


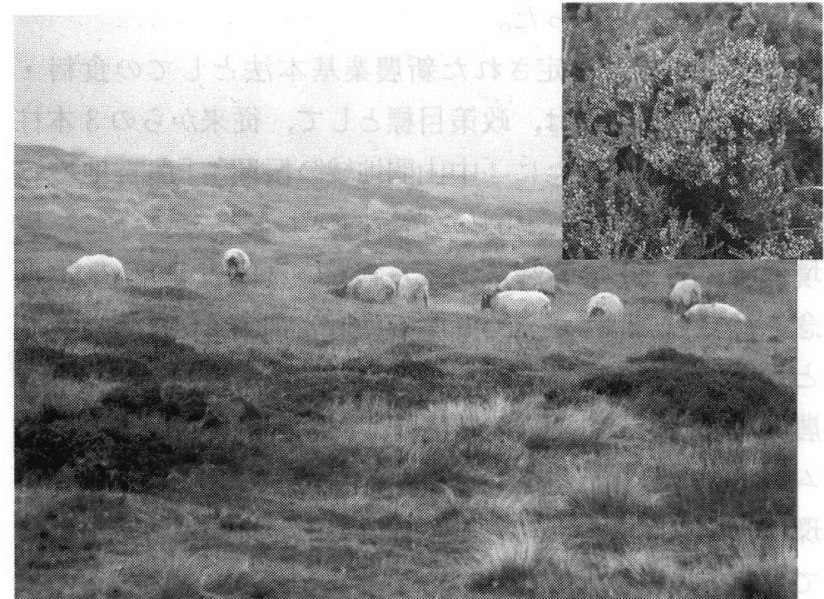

写真 $-1 \quad$ イギリスのムーアランドの景観

写真中央に写るヒッジの放牧が, 水河時代から続く景観を維持してきた

リス中部のムーアランド（ヒースの茂る荒野）では，放牧 されたヒッジがヒース以外の草本類を選択的に採食した結 果, ヒースやライチョウなどを構成種とする氷河時代の名 残りの生態系が，今日まで生き長らえたとされる。ヨーロッ パの自然環境の大半は, 農業が形作った二次的自然という わけだ（Rackham, 1994)。

ところが戦後，急速に進んだ大規模集約的な農業は，そ れまでの粗放的な農業形態に依存してきた生態系を破壊す るむのとなった。美しい景観と豊かな生物相を取り戻すに は，農業をむう一度，かつてのような粗放的な状態に戻せ ばいい。粗放化農業政策は，そうした発想にもとづくもの といえる。もちろんその背景に, EU諸国での農産物の生 産過剰という事情があることも，見逃してはならない。

日本においても, 中山間地域の振興策や農業保護策の一 環として, 環境保全を名目とした補助金の支払いが議論さ れている。棚田をはじめ環境保全上重要とされる農地を, 農家に対する直接的な所得補償（いわゆるデカップリング） によって保全しょうというあのである。すでに補助金の交

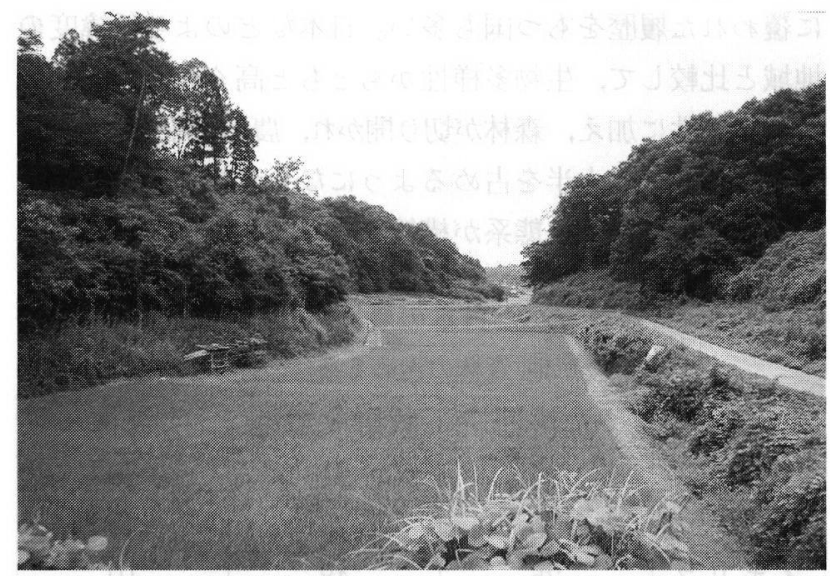

写真－３伝統的な谷津田（埼玉県）

伝統的な農業形態が形成する空間が, 農村に固有の生物相の保全にとって重要

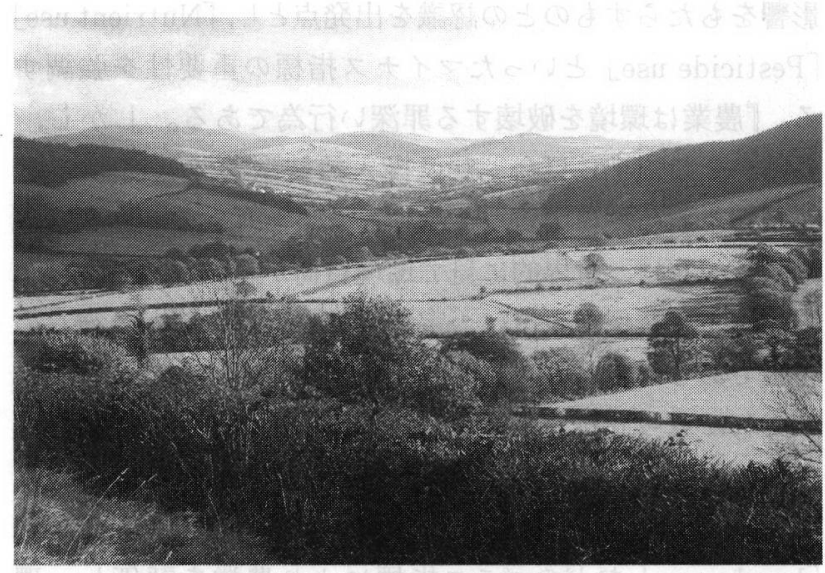

\section{写真－２ウエールズの田園景観}

粗放化農業は,こうした景観の保全と生物 相保全を同時に達成するものとされる

付を開始した自治体むある。今後こうした補助策はます ます増加することだろう。

しかし日本の場合，EU 諸国のような粗放化農業という 概念は成立しない。温帯モンスーンにあり生物多様性がも ともと高い, 牧野・草地がほとんど存在せず（表 3 ）水田 が農地の大半を占める, 労働集約的な農業形態が基本をな す, といった条件のむとでは, 粗放化は事実上の「放棄」 であり，農地としてのアイデンティティの喪失を意味する。 日本では, 環境保全を目的とした政策であっても, 農地と しての「管理」を前提とする必要があるといえる。

景観や生物相の保全を図る際の具体的な方策む, $\mathrm{EU}$ 諸 国とは異なる。 $\mathrm{EU}$ 諸国の粗放化農業政策は, 景観と生物 相の保全を同時に達成するものとされる。しかし日本の場 合, 景観保全と生物相保全は, 必ずしも同じ解を意味しな い。守山（1997）は，大規模集約化以前の，いわゆる伝統 的な農業形態が, 農村に固有の生物相の保全を図ってきた とする (写真 3)。しかし Yokohari et al. （1994）や田 野倉ら（1998）, 松本ら（1999）功指摘するように, 人々 が最も好む日本の農業景観は, 写真 4, 5 のような大規模 な農地の景観である。戦後の大規模集約的な農業の展開は, 少なくとも景観保全機能にとっては，むしろプラスに作用 したことになる。農地としての管理を前提とする点におい ては一致するものの, 望ましいとされる農業の形態は, 景 観保全と生物相保全では，かなり異なるものといえる。

\section{目的としての環境保全 : 政策転換の必要性}

以上概観してきた WTO や OECD における議論，ある いは農業基本法の改正が象徵するように，農政における環 境保全の位置づけは，極めて高いものとなりつつある。し かし注意すべきは，国内外を問わず，これら一連の政策は 元来, 農業ないしは農家の保護が目的であり, その手段と して農業の環境保全機能が言及されているという事実であ 


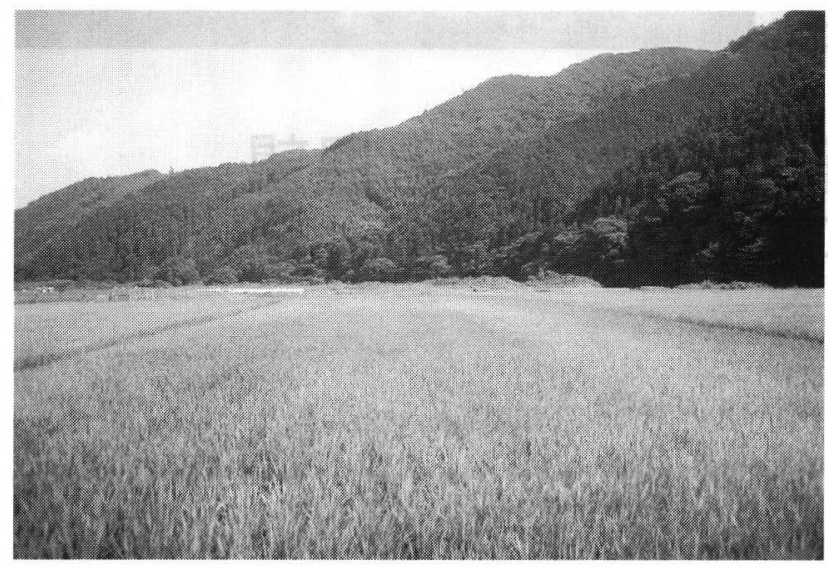

写真一 4 好まれる水田景観（埼玉県）

広大な水田之背後の斜面林の組み合わせが, 最も好ましい水田景観とされた

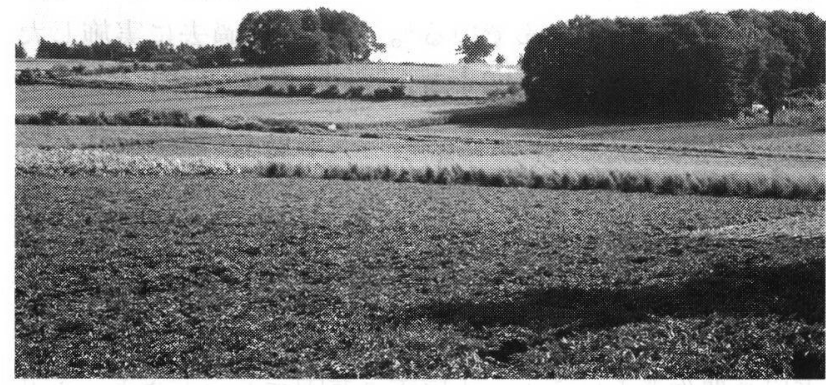

写真ー 5 好まれる畑地景観（群馬県）

あたかもヨーロッパのような森林をともなった 広大な畑地が,最む好ましい畑地景観とされた

る。粗放化農業といえどす，環境保全は農業・農家を保護 するための名目であって，環境保全そのあのが政策目標な わけではない。

また，歴史を振り返っても，環境保全は結果として担保 されてきたのであり，農村を維持・管理する上での目的で あったわけではない。農業生産を目的とした行為が, 結果 的・副次的に美しい景観を生み，生物相を扶養してきた。 美観の形成や生物相の保全を目的に，農業が営まれてきた のではない。

しかし, 農業人口の減少や高歯化, 農産物の貿易自由化 などにより，さらに加速すると言われる農業の大規模集約 化・機珹化は，従来の農業が結果的・副次的にもっていた 環境保全機能を啔失する方向に作用する場合が多い。『環 境保全のためには農地の管理が必要』は正しいとしても, 『農業がきちんと営まれていれば, 環境保全は結果的につ いてくる』という構図は, すでに過去のものとなりつつある。 $\mathrm{EU}$ 諸国は, 生産過剩という現実に対する営農上の目標 と, 様々な環境保全上の目標に共通のリファレンスを過去
の農業の姿に求め, 粗放化農業という政策目標をかかげた。 日本では, 農業生産と環境保全でリファレンスが異なるの みならず，個々の環境保全機能ごとにも，目標之なる農業 像が異なる。『生産機能を基調に，それを補強するものと して環境保全に言及する』というスタンスは, 通用しない。

「環境の世紀」とされる 21 世紀には, 社会の基軸が 「経済」加ら「環境」へ移行するとされる。環境保全に対 する一般市民の関心む，高まりこそすれ低下することはな い。そうした社会の動向に呼応した農政のあり方として求 められるのは, 環境保全の明確な目的化だろう。生産至上 であった従来の農政が，世紀末に至ってようやく，環境保 全をむ視野に入れるようになった。21 世紀には, 結果と して充足される環境保全ではなく，明確に目的化された環 境保全が望まれよう。環境保全を結果加ら目的へ。そうし た発想の転換が，21 世紀の農政には強く求められる。

\section{引用文献}

1) 和泉真理（1989）: 英国の農業環境政策：富民協会, pp.206

2) Kato, Y., M. Yokohari, and R.D. Brown (1997): Integration and visualization of the ecological value of rural landscape in maintaining the physical environment of Japan: Landscape and Urban Planning 39 (1), 69-82

3) 守山 弘 (1997)：水田を守るとはどういうことか： 農文協, pp.205

4 ) 松本 聡・横張 真 - 加藤好武 - 山本勝利 (1999)： 畑地景観保全のための地域住民による畑地景観の評価 構造の把握 : 農村計画学会論文集 1, 49-54

5 ) OECD (1997): Environmental Indicators for Agriculture: OECD, Paris, pp.62

6) OECD (1999a): Environmental Indicators for Agriculture; Concepts and Framework: OECD, Paris, pp. 45

7) OECD (1999b): Environmental Indicators for Agriculture; Issues and Design: OECD, Paris, pp. 213

$8)$ Rackham, O. (1994): History of the Countryside: George Weinfield \& Nicolson, London, pp.240

9 ) 田野倉直子 ・横張 真・山本勝利 - 加藤好武 (1999): 地元住民による水田景観の認知構造 : ランドスケープ 研究 62 (5), 727-732

10) Yokohari, M., R.D. Brown and K. Takeuchi (1994): A framework for the conservation of rural ecological landscapes in the urban fringe area in Japan: Landscape and Urban Planning 29, 103-116 